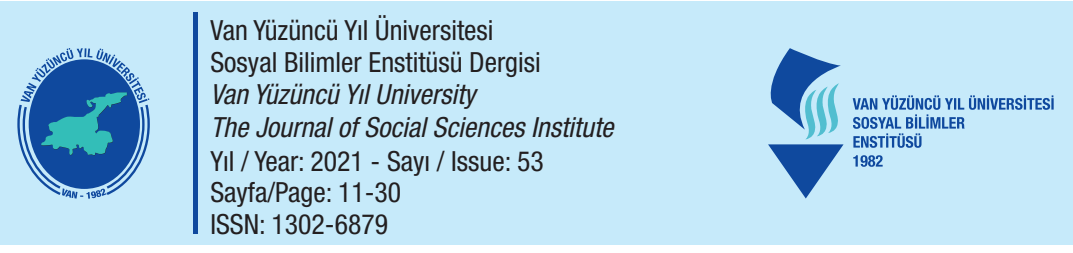

\title{
Traditional Turkish Sweet Bread Discovered in Famine: Pear Bread*
}

\section{Kıtlık Zamanı Ortaya Çıkan Tatlı Bir Türk Ekmeği: Armut Ekmeği}

\section{- Abdullah BADEM*}

* Dr., Karamanoğlu Mehmetbey University, Vocational School of Social Sciences, Department of Hotel, Restaurant and Catering, Karaman/Turkey.

Dr., Öğr. Üyesi, Karamanoğlu Mehmetbey Üniversitesi, Sosyal Bilimler Meslekyüksek Okulu, Otel, Lokanta ve İkram Hizmetleri Bölümü,

Karaman/Türkiye.

abdullah_badem@yahoo.com

ORCID: 0000-0001-8518-6366

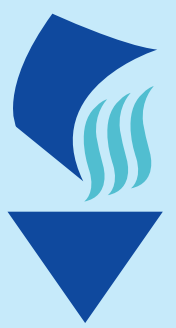

Makale Bilgisi I Article Information Makale Türü / Article Type: Araștırma Makalesi/ Research Article Geliș Tarihi / Date Received: 05/07/2021

Kabul Tarihi / Date Accepted: 01/09/2021

Yayın Tarihi / Date Published: $30 / 09 / 2021$

Citation: Badem, A. (2021). Traditional Turkish Sweet Bread Discovered in Famine: Pear Bread. Van Yüzüncü Yıl University the Journal of Social Sciences Institute, 53, 11-30.

Atıf: Badem, A. (2021). Kıtık Zamanı Ortaya Çıkan Tatı Bir Türk Ekmeği: Armut Ekmeği. Van Yüzüncü Yıl Üniversitesi Sosyal Bilimler Enstitüsü Dergisi, 53, 11-30.

\section{Abstract}

Bread, one of the basic nutritional and staple foods for many societies today, is almost as old as the history of humanity. Loaf, yufkaphyllo, bazlama-flatbread and tandir-tandoori varieties of bread are widely made in Turkey. Inherited from our ancestors, yufka is frequently made throughout Turkey. Wild pear, which is also known by names such as "ahlat, gray pear, etc.", which grows in mountainous regions in Konya, was used in making phyllo bread, especially in times of famine. In this study, pear bread made in Konya, especially in the mountainous parts, was investigated. In this study, which is a qualitative research method, 14 semi-structured questions about the production and history of pear bread were asked to 13 people ( 8 women and 5 men) selected by purposive sampling method in May 2021. Pear bread can be used as an important gastronomic element and it is an important bread type in terms of health thanks to its bioactive compounds, and also its taste and aroma. It can be used to promote the region. Today, pear flour is also used in cake making. In this context, it is thought that different bakery products can be produced by using pear flour.

Keywords: Pear flour, sweet bread, fruit and vegetable flour, traditional bread, Turkish cuisine, cultural heritage.

* The ethics committee permission document required to collect the data used in this study was obtained from the Ethics Committee of Karamanoğlu Mehmetbey University (26.04.2021/52). 


\section{$\ddot{O} \mathbf{z}$}

Günümüzde birçok toplum için temel besin ve temel gıdalardan biri olan ekmek, neredeyse insanlık tarihi kadar eskidir. Türkiye'de somun, yufka, bazlama ve tandır ekmekleri yaygın olarak yapılmaktadır. Atalarımızdan miras kalan yufka, Türkiye'nin her yerinde sıklıkla yapılır. Konya'nın dağlık bölgelerinde yetişen "ahlat, boz armut vb." gibi isimlerle de anılan yabani armut, özellikle kıtlık dönemlerinde yufka ekmek yapımında kullanılmış olup halen bu gelenek devam ettirilmektedir. Bu çalışmada Konya'da özellikle dağlık kesimlerde yapılan armut ekmeği incelenmiştir. Nitel bir araştırma yöntemi olan bu çalışmada, amaçlı örnekleme yöntemiyle seçilen 13 kişiye (8 kadın ve 5 erkek) Mayıs 2021'de armut ekmeğinin üretimi ve tarihçesi ile ilgili 14 yarı yapılandırılmış soru sorulmuştur. Önemli bir gastronomik unsur olduğu düşünülen armut ekmeği, kendine has tat ve aroması, içerdiği biyoaktif bileşikler ile sağlık açısından önemli bir ekmektir. Bölgenin tanıtımı için kullanılabileceği düşünülmektedir. Günümüzde armut unu kek yapımında da kullanılmaktadır. Bu bağlamda armut unu kullanılarak farklı unlu mamüllerin üretilebileceği düşünülmektedir.

Anahtar Kelimeler: Armut unu, tatl ekmek, meyve ve sebze unu, geleneksel ekmek, Türk mutfağı, kültürel miras.

\section{Introduction}

Bread is one of the basic food sources that human beings cannot give up. There are very few places in the world where bread is not consumed (Betoret \& Rosell, 2020: 9). Bread is one of the main ingredients of the daily diet in many countries (Yu et al., 2017: 3). With the beginning of agriculture and the discovery of fire, bread was started to be made as a result of cereals (especially wheat) being crushed and made into flour. In primitive living conditions, people were fed by collecting fruits and seeds, etc., and crushing them with stones. Over time, people cultivated grains such as wheat, barley, millet and oats, and bread varieties were derived from their flour.

Turkish cuisine has become one of the few cuisines of the world, with the process of change from Central Asia to the present day. While transitioning from a nomadic life to a settled life, nutrition activities started to be carried out with the foods obtained as a result of geographical and economic conditions (Göde et al., 2021: 217).

\section{Yufka bread - phyllo bread}

Many types of bread have emerged after the tradition brought by the Turks from Central Asia, where they used to live, and the interaction with the cultures of the nations that lived in the past in Anatolia. It is known that the Hittites, who used to rule in Anatolia in the past, made many breads, that the breads they made have reached the present day, and that they have influenced the formation of today's 
breads (Karauğuz, 2007). There are many types of bread made in Turkey. The most common ones can be listed as loaf, yufka-phyllo, bazlama-flatbread, tandir-tandoori, corn bread and lavaş-lavash. It is known that bread types such as yufka-phyllo, tandir-tandoori, pide-pita, bazlama-flatbread, fodula etc. have been widely made in Anatolia since the Seljuk period, all over Turkey (Badem, 2021: 265). It is known that yufka is the most widely made and consumed bread in Central Asia (Çetinkaya, 2020: 128). The most well-known among the breads baked on the sheet metal "sac" is yufka bread. Information about yufka published by Badem (2021: 280):

Yufka, which originates as far back as Central Asia and is widely made in Anatolia, is a type of unleavened bread, 1-2 $\mathrm{mm}$ thick, $40-50 \mathrm{~cm}$ in diameter, cream colored, single layered, baked on a sheet metal. Yufka, which has a very dry structure, lasts for a long time with this feature. Before consumption, it is softened by wetting it with water sprinkled on it thinly. While the production of yufka is similar in most regions, its name changes locally, but the name " $y u f k a$ " is widely used. In some regions, for examples, yufka is named as "şebit, sepit, şipit" in Tekirdağ, Afyonkarahisar, Konya, "işkefe" in Tokat, Amasya, "gardalaç" in Tokat, Eskişehir, Ankara and "gartalaş" in Bursa, Bolu and Eskişehir.

Yufka bread is a round or oval shaped thin bread that is rolled out by rolling pin "oklava" or by hand. In order to the dough to be rolled out, it must be made of flour that can develop well, so it is often made from flour that wheat species such as Triticum avestivum. Small pieces of dough called "beze" or "künt" are taken from the kneaded dough with a traditional kitchen tool called "eysiran" or "scrape" and it is opened on a wooden opening board called "senit" or "peşkın". In order to the dough to be more durable, it is made from unleavened dough and cooked on a sheet metal "sac". A flat wooden kitchen tool called "pişirgeç" or "evreağaç" is used to turn the dough during cooking (Kültür ve Turizm Bakanlığı [KTB], 2021; Alyakut, \& Küçükkömürler, 2018: 385).

"Pişik umacı", "tirit from yufka bread", "ufalamaç", "pasta with yufka bread", "böreks and gözlemes - pastries" prepared with minced meat, etc., "mendil-handkerchief" (reparation of yufka bread by soaking and stuffing cheese, etc. in Kocaeli region.), and "yufka bread dessert" are some of the dishes made from yufka bread (Alyakut, \& Küçükkömürler, 2018: 388). It is a bread that is loved and consumed by 
Turkish society. In addition to being consumed as a loaf bread, it is eaten by putting it among foods such as kebabs, çiğ köfte-raw meatballs, dürüm with meat-chicken, tantuni, kokoreç, also potatoes, cheese, roasting meat.

The word "ekmek-bread" is pronounced as "etmek, ötmek" in old Turkish. "Yufka", which comes from the word "yuwka" in Central Asian Turkish, means weak, kind or merciful (Alyakut \& Küçükkömürler, 2018: 383-384). The name of the thin and crispy yufka must have been given for this reason.

\section{Wild pear - ahlat pear}

Wild pear (Pyrus elaeagrifolia subsp. elaeagnifolia Pall.), Oleaster-leafed pear, which is usually known as "ahlat, yaban armudu" in Turkish (Sagbas et al. 2021: 1; Yilmaz et al., 2015: 179), a member of the Rosaceae family, naturally grown, more than 600 varieties, geographic distribution-site of origin Turkey, Ukraine, Albania, Bulgaria, Greece, Romania and Crimea (Erçetin et al., 2021: 675; Silva et al., 2014: 5; Ercisli 2004: 422), is commonly grown in cities in Turkey especially North, Central and South Anatolia; such as Amasya, Ankara, Antalya, Bolu, Eskişehir, Gümüşhane, İstanbul, Kahramanmaraş, Kars, Kastamonu, Kayseri, Konya, Kütahya, Mersin, Muş, Niğde, Sinop, Sivas,Van (Orman Genel Müdürlüğü [OGM], 2021; Baltas 2017: 585; Ercisli 2004: 422,). It dates back to ancient times. Civilizations using pear and wild pear: Hittites, Mesopotamia, Ancient Rome, Central Asian Turkish State, Anatolian Seljuk State, Ottoman Empire (Erçetin et al., 2021: 675). Wild pear tree and fruits is given Figure 1. The local names for wild edible pears vary from place to place "yabani armut, boz armut, aklap, alfat, argun, banda, çördük, çötür, çövür, kerte, panta, ahlat and zingit" in Turkish (OGM, 2021). The pear shows high drought and cold resistance (Ercisli 2004: 422). Wild pear is a tree growing up to a height of $10 \mathrm{~m}$, its leaves and flowers are ovate, slightly serrate, small and white, respectively. Its fruit is small and roundish, growing up to $2 \mathrm{~cm}$ in length (Zbigniew et al. 2014: 337). Wild pear trees flower between April and May and the fruits mature in October and November (Sagbas et al., 2021: 2). 


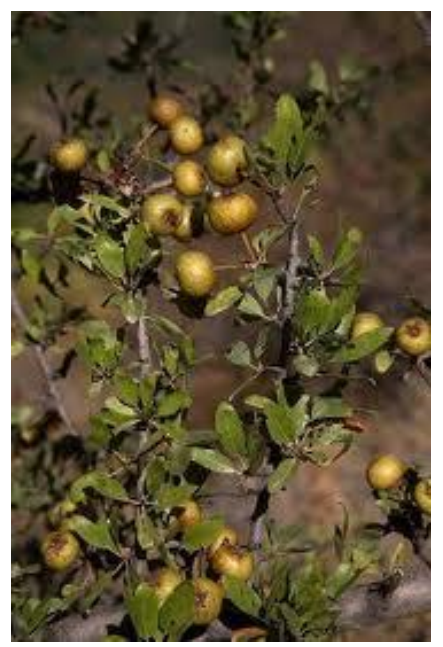

Figure 1: Wild pear fruits (Photo: OGM, 2021).

Wild pear is consumed as food (edible fruits; eaten fresh or dried, syrup-pekmez, preserves, pickles, alcoholic beverages, dried fruit is used in making compote), and is used as folk medicine, wood source and dietary supplements, rich salubrious biochemical compounds (Aydin et al., 2015; Yilmaz et al., 2015: 179; Yerlitürk et al., 2008: 369; Cansaran et al., 2007: 252). Pear seeds were roasted and then toasted (it is called as "kavut" in Turkish), used substitute for tea or coffee in Turkey. It is also used in traditional medicine such as treatment of diarrhea and detoxification of poisonous snake bites, intestinal ulcers, nausea and palpitations (Sagbas et al., 2021: 1; Baltas, 2017: 585; Yilmaz et al., 2015: 179; Yerlitürk et al., 2008: 369). Local people also brew the leaves and dried fruits are pestle and resultant coffee-like roasted powder is used in compote (Yilmaz et al., 2015: 180).

Pear leaf is rich in a glycoside called arbutin and is widely used in the treatment of freckles, spots and acne on the skin. A pear species that is endemic in Turkey contains high levels of arbutin (Kayhan et al., 2020: 91). Some genotypes of pear contain high phenolics, flavonoids, antioxidant activity. It has potential use in bio-industrial applications (Sagbas et al., 2021: 9). Wild pears contain 8,36-19,31 g/100 g total sugar, 42,79-119,14 mg/100 g total phenolics, and 0,20-1,40 g/100 g total acidity (Yilmaz et al., 2015: 183). The taste and aroma of the fruits have a refreshing effect on human and it has been stated that the leaves of the pear are brewed in Turkey (Yilmaz et al., 2015: 179).

"The characteristics of oleaster-leafed pear fruits relative to genetic background were evaluated from 16 wild grown oleaster-leafed pear genotypes at eastern Turkey. Genotype influenced ripening dates, 
fruit weight, fruit length/width ratio, fruit pedicel length, fruit flesh texture, fruit firmness, the number of seeds per fruit, soluble solid content, titratable acidity, total phenolic content, total flavonoid content and antioxidant activity" (Sagbas et al., 2021: 1). "Fruit weight, total phenolics, total acidity and total sugar contents of the fruits (31 genotypes of wild pears) varied from 4.71 to $27.09 \mathrm{~g}$, 42.79 to 119.14 $\mathrm{mg} \mathrm{GAE} / 100 \mathrm{~g}, 0.20$ to $1.40 \mathrm{~g} / 100 \mathrm{~g}$ and 8.36 to $19.31 \mathrm{~g} / 100 \mathrm{~g}$, respectively. Wild pear is rich source of phenolics" (Yilmaz et al., 2015: $179,183)$.

\section{Fruit and vegetable flours}

Bread making process is easy, low cost, neutral taste, so it can be eaten with almost everything, and it also has a good structure for enriching its content. For the production of healthy bread, it is seen that many studies have been carried out to increase the content of bread with fruit and vegetables" additives such as bioactive compounds, dietary fiber, carotenoids, polyphenolics, tocopherols, minerals, organic acids, antioxidants, vitamins C (Rahman et al., 2021; Betoret \& Rosell, 2020; Parafati, 2020; Gomez \& Martinez, 2017; Mastromatteo et al., 2012). Various foods such as artichoke, asparagus, pumpkin, zucchini, tomato, yellow pepper, carrot, broccoli, spinach, eggplant, fennel, cauliflower and orange are used to enrich breads (Mastromatteo et al., 2012: 1314). Reasons for fruit and vegetable use: citrus; ascorbic acid, berries; flavonoids, anthocyanins, algae; fatty acid profile, pumpkin, yellow pepper, and tomato; carotenoids, beetroot and carrot; glycosylates and carotenoids, spinach, and chard; folic acid, pea; fiber, herbs and spices" extracts; polyphenol (Betoret \& Rosell, 2019: 12).

While most of the bread additives are added in powder form, some of them can be added directly to the composition in fresh or puree or liquid form (from $0.5 \%$ of algae to $50 \%$ of pumpkin ratio) (Betoret \& Rosell, 2019: 12)

Proteins in cereals have a serious role in bread making. Wheat proteins such as glutenin and gliadin take water and form bonds during the kneading of the dough, significantly affecting the properties of the dough and providing an elastic and plastic structure. Proteins form the main structure of the dough and keep the air added to the dough during kneading and the carbon dioxide $\left(\mathrm{CO}_{2}\right)$ gas created by the yeast (Saccharomyces cerevisiae) in the dough, allowing the bread to rise and have a porous structure.

In addition, bioactive components such as antioxidants and polyphenols originating from fruits and vegetables can affect the activity of yeast (Saccharomyces cerevisiae) positively or negatively. 
This effect is caused by the $\mathrm{pH}$, vitamin, protein, carbohydrate and mineral substances contained in the added fruit-vegetables (Parafati, 2020: 2). In addition, the formulation rich in bioactive compounds such as phytochemicals does not guarantee the functionality of the additive. For this reason, it is necessary to pay attention to the compatibility of the matrix such as the fruit and vegetable to be added and the flour to provide good stability (Betoret \& Rosell, 2020: 12).

Adding fruits and vegetables is an effective technique to increase antioxidants to improve the antioxidant potential of bread, but the quality and biological effect of bread is affected by many factors such as phenolic and protein interactions. These interactions between added fruit-vegetable phenolics and flour proteins and starch affect the antioxidant capacity, protein and starch digestibility, and the quality and physical and functional properties of bread (Betoret \& Rosell, 2019: 16-17; Gomez \& Martinez, 2017: 1).

Soybean, beans, legumes, peanuts, oilseeds (cotton, sesame, sunflower, safflower, winged bean, lupine, and sunflower) and nonwheat flours (sorghum, millets, corn, oat, rye, triticale, rice, rice bran, amaranthus, tapioca flour, or barley) can be added to bread to enrich it (Chavan et al., 1993: 200-208). Amaranth, quinoa and buckwheat, which also contain health-rich nutrients such as fruits and vegetables, are other cereals used for bread making due to the absence of gluten protein. These cereals, which contain high amount and quality protein, dietary fiber, unsaturated fatty acids, vitamins, minerals, phytosterols and polyphenols, show anticholesterol, anticancer, anti-inflammatory and antidiabetic effects (Yaver \& Bilgiçli, 2020: 42). Oat (Avena sativa L.), a source of high fiber, antioxidant and phenolic substances, which has attracted attention recently, is used in bread fortification due to its antioxidant, anti-inflammatory, hypoallergenic and anticarcinogenic properties (Topçu et al., 2019: 49). Milk and soybean proteins are the most used proteins in bread formulations as protein sources to improve the nutritional quality of gluten-free products (Marco \& Rosell, 2008: 94).

Prickly pear peel flour (PF) is used to make bread as a bioactive and functional ingredient. The bread sample, containing PF at 10\%, has showed the highest values in terms of the leavening dough capacity, bread specific volume (Parafati, 2020: 1).

In this study, the semi-structured questionnaire given in Table 1 was used to collect information about the making and history of pear flour bread. 
Table 1: Semi-structured questionnaire used in the study.

\begin{tabular}{|l|l|}
\hline No & \multicolumn{1}{|c|}{ Questions } \\
\hline $\mathbf{1}$ & How many years have you been making pear flour bread? \\
\hline $\mathbf{2}$ & How often do you make pear flour bread? \\
\hline $\mathbf{3}$ & When do you make pear flour bread? Are there any features of this period? \\
\hline $\mathbf{4}$ & From whom/where did you learn how to make pear flour bread? \\
\hline $\mathbf{5}$ & What are the tools used in making pear flour bread? \\
\hline $\mathbf{6}$ & $\begin{array}{l}\text { What ingredients do you use when making pear flour bread? Could you give information } \\
\text { about the size of the ingredients? }\end{array}$ \\
\hline $\mathbf{7}$ & Do the ingredients you use to make pear flour bread have any unique properties? \\
\hline $\mathbf{8}$ & Can you tell us the stages of making pear flour bread? \\
\hline $\mathbf{9}$ & $\begin{array}{l}\text { When making pear flour bread, what should be considered in order to provide the desired } \\
\text { color, taste and flavor? }\end{array}$ \\
\hline $\mathbf{1 0}$ & How do you serve pear flour bread? Do you have a unique service style? \\
\hline $\mathbf{1 1}$ & Is pear flour bread suitable for preservation? How should it be preserved? \\
\hline $\mathbf{1 2}$ & Do you know how long pear flour bread has been made in Hadim in Konya? \\
\hline $\mathbf{1 3}$ & $\begin{array}{l}\text { Does pear flour bread have a local name/other name in your region? Does pear flour } \\
\text { bread have a story/poem/mania? }\end{array}$ \\
\hline $\mathbf{1 4}$ & Are there any other foods made with pear flour? What are they? \\
\hline
\end{tabular}

\section{Method}

Pear flour bread is a bread made in some regions and its production is decreasing day by day. For this reason, with this qualitative research, it is aimed to record the production, details and history of pear flour bread. For this purpose, one-to-one interviews were held in semi-structured format with 13 volunteers who know how to make bread, on May 2021. In unstructured interviews, it is stated that the sample size is between 6-8 people. Interviews were terminated by repeating the answers and reaching the saturation point (Creswell \& Creswell, 2018: 298). In order to ensure reliability in qualitative research methods, it is necessary to specify how the data is analyzed (Kozak, 2018: 124). Strategies used to ensure validity and reliability in qualitative research are expressed as "long-term interaction, depthfocused data collection, diversification, expert review, participant confirmation, detailed description, purposeful sampling, consistency review, and confirmation review". In this study, depth-oriented data collection, expert review, participant confirmation and purposive sampling were applied for validity and reliability. Pear bread is made by people living in mountainous regions where pears are grown. The interviewees were selected from people residing in Hadim, Konya, Turkey, and this constitutes the limitation of this research. During the interviews, video or voice recordings were taken with the permission of the participants, and some of them were made with pear bread. Interviews took between 20-30 minutes on average. The recorded interviews were transcribed. The collected data were transcribed, edited, and commented in the results and discussion section. 
Descriptive analysis method was preferred as data processing approach. The questions prepared to be answered in the study (14 open-ended questions) were taken from a previous food research (Badem \& Akturfan, 2020) of 7 academicians who teach in the field of gastronomy at three universities. The ethics committee permission document required to collect the data used in this study was obtained from the Ethics Committee of Karamanoğlu Mehmetbey University (26.04.2021/52).

Information about the participants interviewed in the study is given in Table 2. In the research, a total of 13 people were interviewed, 9 women and 4 men. One of them is 30 years old and the rest are between the ages of 44-86.

Table 2: Demographic information of the participants.

\begin{tabular}{|l|l|l|l|l|l|l|}
\hline $\begin{array}{l}\text { Part. } \\
\text { Cod } \\
\text { e }\end{array}$ & $\begin{array}{l}\text { Name } \\
\text { Surname }\end{array}$ & Gender & $\begin{array}{l}\text { Birth } \\
\text { Date }\end{array}$ & Hometown & Occupation & Education \\
\hline P1 & M.S. & F & 1964 & Hadim/Konya & Housewife & Primary \\
\hline P2 & F.V. & F & 1967 & Hadim/Konya & Housewife & Primary \\
\hline P3 & E.A. & F & 1977 & Hadim/Konya & Housewife & Primary \\
\hline P4 & M.C.. & M & 1952 & Hadim/Konya & Retired & Primary \\
\hline P5 & E.M.T. & M & 1935 & Hadim/Konya & Retired & Primary \\
\hline P6 & H.A. & F & 1968 & Hadim/Konya & Housewife & Primary \\
\hline P7 & D.A. & M & 1963 & Hadim/Konya & Retired & High School \\
\hline P8 & K.Y. & F & 1935 & Hadim/Konya & Housewife & Primary \\
\hline P9 & E.Y. & F & 1938 & Hadim/Konya & Housewife & Primary \\
\hline P10 & N.G. & F & 1953 & Hadim/Konya & Housewife & Primary \\
\hline P11 & D.A.M. & M & 1938 & Hadim/Konya & Retired & Primary \\
\hline P12 & H.M. & F & 1938 & Hadim/Konya & Housewife & Primary \\
\hline P13 & L.A. & F & 1991 & Hadim/Konya & Teacher & University \\
\hline
\end{tabular}

\section{Results}

The information obtained from the questions asked in the interview is presented below:

\section{How often do you make pear flour bread?}

How many years have you been making pear flour bread?

This information was obtained from the participants: "Pear bread was done in times of famine." (P1-12), "There was extreme famine in the 1930s-40s." (P6), "It was also done before the time of famine, there was also pear flour in the 1900s." (P5), "Today, it is rarely made for tasting (P6-9), mostly in the winter months." (P1-9,11,12). "Since we can't grind the pear, we can't do pear bread anymore." (P10).

Bread making was common in Turkish society until recently. This situation does not seem to have changed much, especially in rural areas, but it is observed that the increase in migration from the village 
to the city, the increase in the level of welfare and the facilitation of transportation opportunities also affect the conditions of daily life. Even in the villages, it is seen that there are one or more groceries, markets, bakeries and restaurants-like businesses. In parallel with this, making bread at home and even grinding their own flour seems to have decreased considerably. It is known that even the production of their own eggs, milk, yoghurt, cheese and butter, which is natural in village life, has decreased.

\section{bread?}

From whom/where did you learn how to make pear flour

All of the interviewed women and men living in Hadim in Konya stated that they learned how to make pear bread and meals either from their mothers or from elders such as their mother-in-law.

\section{When do you make pear flour bread? Are there any features of this period? \\ Do you know how long pear flour bread has been made in Hadim in Konya?}

It has been learned that while the winter was coming and the preparations for the winter were made, pear flour bread was also made with yufka bread, but today, pear bread is made at any time for pleasure (P1-13). It is also stated that "Pear bread is made and sold at festivals." (P9). Winter preparations include activities such as drying vegetables, pickling, canning, making tomato paste and jam. In some regions, it is often seen that village women make tandoori bread and yufka bread together in turn. A participant (P3) stated that "They make 1 direk-pole of şebit-shebit; yufka bread and 1 pole pear bread ("direk"-pole: rowing 500-100 pieces of yufka on top of each other)". In addition, it was determined that pear, which is named as "ahlat, boz-gray pear, yabanwild pear, famine pear" (P1-13) and bread is made more after harvest months (P1-12), as it is harvested when it is ripe like OctoberNovember. It was stated that "the pear was named -famine pearbecause the trees in only one region once bore fruit, and all peasants shared the pear in that mountain" (P6). In "times of famine" (P1,2, 412), especially "between 1930-1945" (P5-9, 11, 12), pear flour bread was made a lot, and "even pear flour bread was known in pre-famine dates, it was around 1900." (P6, 11, 12). This information was given by the participant (P6); "My mom is now 90, she told me she remembers making pear bread at the age of 4 and her mother making bread from pear flour." 


\section{What are the tools used in making pear flour bread?}

In making pear flour bread, equipments such as "tray, basin, oklava, senit, knife, pişirgeç-cooker and sac-sheet metal" used when making normal breads are used, and no special equipment is needed.

\section{What ingredients do you use when making pear flour bread? Could you give information about the size of the ingredients?}

Pear flour is one of the main ingredients in making pear bread. Pears are collected from the mountain in October-November. There are different kinds of pears, "the sweeter ones are gathered to make flour, the others are gathered to feed animals" (P3), "there are many crazy pears in the mountains, we choose the best." (P5). Pear stems, leaves, litter, etc. are separated $(\mathrm{P} 1,2,3,4,6,8,9)$. The pears are pounded "to remain large pieces" $(\mathrm{P} 4,5)$, "on a flat stone called a "duvak"-veil with sackcloth laid under it" (P4,5,6,9,11,12), "with a "tokmak"-mallet (hammer made of wood- Picture 2) (P1,2,4,5,6,9,11,12). "It is dried in the sun in 5-7 days by laying it on a sack, rug or mat." (P6.8). It is ground in "watermills, black stone" (P4,5), "mills" (P6,9). Dried pear and pear flour images are given in Figure 2. While pear is called "wild pear, gray pear, ahlat" (P1-13), it is called "kükürt-sulfur for dried pear and pear flour" (P1-13), but no one knows why. Dried pear is mixed as "one measure with wheat flour" $(\mathrm{P} 1,2,6,8,10,11,12)$, or "half measure with wheat flour" $(\mathrm{P} 3,5)$. Flour is obtained by "grinding the mixture in the mill." (P1,2,4,5,9,10). Essentially, the proportion of the mix was determined by the materials available, especially during times of extreme shortage. It has been stated that in some years, "flour was increased by mixing barley, rye and dried pear when there was no wheat" $(\mathrm{P} 11,12)$. As many participants stated, different herbs were also mixed into the flour in order to increase the mixture of pear flour and wheat. For example, "corn stake-cob" was cut into small pieces (P47,9,11,12), "dried grass" (P5), "fin grass" (P5,7-9), "curba (seed pulp from which juice is separated in pekmez-molasses production)" $(\mathrm{P} 6,8,11,12)$, "musket potatoes" $(\mathrm{P} 6)$, and "barley, rye" $(\mathrm{P} 11,12)$ were dried and often added to bread flour. In addition, edible herbs such as "güneyik-sage grass, gelincik-poppy grass" (P8), "potato leaves, fodder, spinach, beet leaves" (P9) are cut into the dough and the dough is increased, also "herbed bread, potato bread is often made" $(\mathrm{P} 11,12)$. 

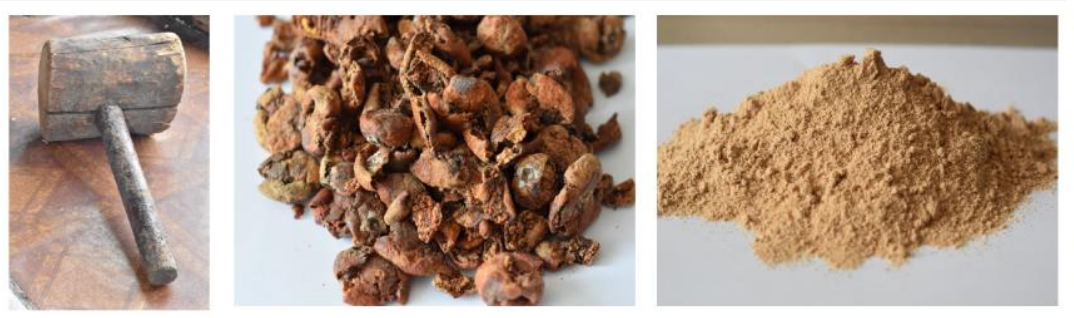

1.

2.

3.

Figure 2: Tokmak-hammer, dried pear and pear flour (Photo: Abdullah BADEM).

\section{Can you tell us the stages of making pear flour bread?}

When making pear flour bread, what should be considered in order to provide the desired color, taste and flavor?

Do the ingredients you use to make pear flour bread have any unique properties?

The making of pear bread is as follows: "The dough is prepared by adding a little salt to the pear flour-wheat mixture and kneading with enough water to the consistency of an earlobe, and it is cooked on the sheet in a very short time." (P1-3,6,8-10). Bread making steps are given in Figure 3. In addition to these, the following information was obtained: "It absorbs water more than wheat flour." (P3), "If the amount of wheat flour is not high, there will be no bread, the "beze" (small pieces of dough) will not be tight and desired hardness." (P5), "The whiter flour, the better it is opened dough. "...hamur yazllır yani açılır." (P3,8,10), "Pear flour is not very "özlü"-elastic and plastic, it is not good for open-widen (P10), "It is made as much as flatbread." (P10), "Pear bread is sweet." (P5), "Pear kernels are also sweet, they are not separated during grinding." (P5), "It will be more delicious if less white (wheat) flour is added." (P3), "The bread mixed with fin grass would not taste good, it would smell a little bad, but we had to eat it because there was not wheat bread." (P5,9), "Bread made with corncob is whiter in appearance, tastes better, but it has dry texture in its nature." (P6), "Pear flour was stored in chests or in objects called "dağarclk" made of sheep skin. In the past, storage possibilities were limited. It was kept in kll çuval-sacks or heybe-saddlebags, in the cool part of the house." (P5). 
How do you serve pear flour bread? Do you have a unique service style?

Is pear flour bread suitable for preservation? How should it be preserved?

Pear bread, which can be consumed as normal bread or yufka (P1-13), is eaten with "boiled potatoes, thyme, peppers, pickles and ayran" (P3), "keş cheese" (P6,9), "yoghurts" (P6). Like phyllo (yufka, shebit) bread, it is consumed "When wet, it lasts for 1 week in a cool place." (P3) or "10-15 days" (P9), and also "dry bread is much more durable." (P3).

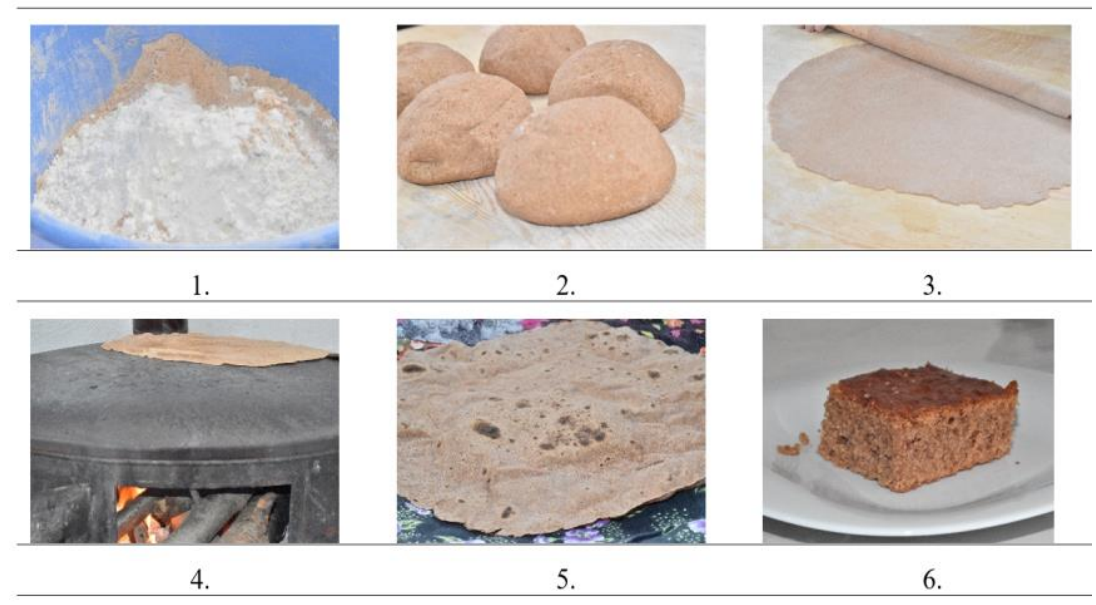

Figure 3: Pear bread making stages (Photo: Abdullah Badem).

they?

Are there any other foods made with pear flour? What are

Today, a kind of cake is made at home in some places using pear flour as a new product. "A cake is made from pear flour, it is also called chocolate cake because of its color." (P1,2,6,13). "The necessary ingredients for making pear cake are: 3 eggs, $1 / 2$ cup of oil, $1 / 2$ cup of sugar, $1 / 2$ cup of pekmez-molasses, $1 / 2$ cup of yogurt, 1 packet of baking powder, 1 teaspoon of baking soda, 2 cups of pear flour, 1 cup of wheat flour. Cake making is follows as: Beat 3 eggs with sugar, and add yogurt, oil and molasses to it. Mix the flour, baking powder and baking soda. Bake in the oven at $180^{\circ} \mathrm{C}$ for $20-30$ minutes." (P13). Pear cake photo is given in Figure 3 (3.6.). 


\section{Does pear flour bread have a local name/other name in your region? Does pear flour bread have a story/poem/mania?}

There is a story told about pear flour: "In times of famine, there is nothing to eat. Someone is tired of beating pears to make flour. He quit his job and took the pear flour-bread to the district governor: $\mathrm{He}$ said that this is the only bread we eat, we are starving, help us. The district governor took the pear bread in his hand and ate it, and he says: -This bread has a rich ingredient-"...katı̆̆ içinde.", so what more do you want, be thankful! -. He did not help the man." (P5,6).

Wild edible plants are a significant food resource. The positive effects of wild vegetables and fruits, which have an important place in the Mediterranean food tradition, are known. Edible wild plants have minerals (García-Herrera, Sánchez-Mata, 2016), vitamins (SánchezMata et al.,2016), fatty acids (Guil-Guerrero, Torija-Isasa, 2016), carotenoids, fiber, phenolics and other bioactive compounds (Cámara et al., 2016) that have many positive effects on health. Today, there is a tendency to research and consume wild edible products in order to be able to eat healthier (Molina et al., 2016: 102-103). It is thought that the necessary value should be given to the wild pear grown in many provinces in our country. More benefits can be obtained by culturing the species that are suitable for human consumption, especially in terms of taste.

Many foods can be added in bread making, as mentioned in the literature. Many traditional breads are made, especially as a result of mixing cereals and legumes with wheat. In particular, bioactive components found in foods such as fruits and vegetables are successful in enriching bread. Spontaneous sourdough is commonly prepared with cereal flours such as wheat flour and rye flour. Sourdough could improve the quality of gluten-free bread. It has been stated that bread with improved nutritional properties can be made with sourdough in the presence of pear (Yu et al., 2017: 1,4). Yeast bread varieties of pear bread can be developed. In a study, cake was produced with the addition of pear flour. According to sensory analysis results, in terms of general taste, odor and appearance, the most popular cake contains $20 \%$ pear flour (Erçetin et al., 2021:674).

As the participants expressed, pear bread was made out of necessity and poverty, rather than a pleasure or other purposes. In a study, it was found that wheat production fell by half between 19391945 in Turkey (Mülayim, 2018: 57). Throughout history, people have had to eat different plants as agricultural production has declined. 
The following statement made by Sagbas et al. (2021:2) is very meaningful. "Today, despite this long gastronomic history, the use of oleaster-leafed pears is disappearing for various reasons. For example, cultivated pears do not need to be processed before being eaten. In addition, urban migration means that people are forgetting about oleaster-leafed pears and the associated recipes and preparation techniques." People now tend to prefer ready-made, less hassle-free foods.

\section{Conclusion}

Since its existence, human beings have consumed bread almost as a basic food item. Bread is a nutritious, neutral-tasting food that is easy to produce, has a low cost, can be eaten with many foods. It can be said that the bread has a good structure in terms of carrying the raw materials from which it is produced and other food components.

Yufka, phyllo bread, dated backs Central Asia, is one of the widely consumed breads in Anatolia in Turkey. Pear bread is a kind of phyllo bread. There are wild pears in Konya, especially in districts with mountainous terrain such as Hadim, Bozkır and Taşkent. Wild pear, which grows naturally in the mountains, is called by different names such as "ahlat, boz armut, yaban armudu" in Turkish. As the interviewees knew, it is thought that pear flour and bread were made only around Hadim. It has been determined that it is a local bread. Wheat flour and pear flour are mixed in making pear bread. Edible herbs and some foods such as "corn stake-cob, dried grass, fin grass, curba, musket potatoes, barley, rye, güneyik-sage grass, gelincik-poppy grass, potato leaves, fodder, spinach, beet leaves" were also often added to flour in bread making to increase the dough during times of extreme famine. While pear bread was made very often in the past, especially in times of famine, today it is produced mostly for pleasure at home and in Hadim Festival.

Wild pear contains many components that are valuable in terms of health and it is sweet due to its high sugar (8,36-19,31\%). It is also called "sweet bread" because of the sweetness that comes from the pear. In an event in the past, it was stated that pear bread was called "kattğ içinde" in Turkish, because of its sweety, nutritious and satisfying features. Pear bread or flour, which is loved by the local people, is also called "kükürt-sulphur". This bread, which can be described as a kind of sweet bread and made unique to the region, is thought to be a very valuable gastronomic element. It can be used for the touristic promotion of the region. It is thought that different new products can be produced with pear flour, which is also used in cake making recently. Pear flour 
can be used for fortification of foods, in the production of bread for people who are sensitive to sugar and gluten implications.

\section{References}

Alyakut, Ö. and Küçükkömürler, S. (2018). A Traditional Bread Type: Yufka. Journal of Tourism and Gastronomy Studies, 6(3), 379395. doi: 10.21325/jotags.2018.288.

Aydin, E., Baysal, E., Toker, H., Turkoglu, T., Deveci, I., Ozcifci, A. and Peker, H. (2015). Decay Resistance, Physical, Mechanical, and Thermal Properties of Heated Oriental Beech Wood. Wood Research, 60 (6), 913-928.

Badem, A. and Akturfan, M. (2020). A Local Soup: Arabaşı (Arab aş1, Ara aş1). M.C. Küçüktığlı, Y. Seçim, M.M. Adabalı and M. Y1lmaz (Ed.), In: Inspirations from Anatolian Culinary Culture. (p. 38-62). Konya: Konya Metropolitan Municipality Cultural Publications.

Baltas, N. (2017). Investigation of a Wild Pear Species (Pyrus Elaeagnifolia subsp. Elaeagnifolia Pallas) from Antalya, Turkey: Polyphenol Oxidase Properties and Anti-Xanthine Oxidase, Anti-Urease, and Antioxidant Activity. International Journal of Food Properties, 20 (3), 585-595.

Betoret, E. and Rosell, C. M. (2020). Enrichment of Bread with Fruits and Vegetables: Trends and Strategies to Increase Functionality. Cereal Chemistry, 97 (1), 9-19.

Cámara, M., Fernández-Ruiz, V. and Ruiz-Rodríguez, B.M. (2016). Wild Edible Plants as Sources of Carotenoids, Fibre, Phenolics and Other Non-Nutrient Bioactive Compounds. M.C. SánchezMata and J. Tardío (Ed.). In: Mediterranean Wild Edible Plants Ethnobotany and Food Composition. (p. 187-208). New York: Springer Publishing.

Cansaran, A., Kaya, Ö.F. and Y1ldırım, C. (2007). An Ethnobotanical Study (Amasya / Gümüşhaciköy) Between the Vicinity of Ovabaşi, Akpinar, Güllüce and Köseler Villages. Science and Eng. J of Firat Univ., 19 (3), 243-257.

Chavan, J. K., Kadam, S. S. and Ramka Reddy, N. (1993). Nutritional Enrichment of Bakery Products by Supplementation with Nonwheat Flours, Critical Reviews in Food Science and Nutrition, 33 (3), 189-226. doi: 10.1080/10408399309527620.

Creswell, J. W. and Creswell, J. D. (2018). Research Design: Qualitative, Quantitative, and Mixed Methods Approaches. California: Sage Publications. 
Çetinkaya, N. (2020). Orta Asya'dan Selçuklu'ya Anadolu Mutfağı. A Akbaba ve N. Çetinkaya (Ed.). Gastronomi ve Yiyecek Tarihi içinde. (s. 125-137). İstanbul: Detay Yayıncılık.

Erbas, M., Uslu, M. K., Demir, M. and Certel, M. (2010). Effects of Extraction Rates of Wheat Flour on Phyllo (Yufka) Properties at Different Storage Temperatures. Cereal Chemistry, 87 (5), 398-402.

Ercisli, S. (2004). A Short Review of the Fruit Germplasm Resources of Turkey. Genetic Resources and Crop Evolution, 51 (4), 419435.

Erçetin, H. K., Güneş, E. and Olcay, G.S. (2021). Use of Ahlat Flour in Cookie Production, Journal of Tourism and Gastronomy Studies, 9 (2), 674-686. doi: 10.21325/jotags.2021.809.

García-Herrera N. and Sánchez-Mata, M.C. (2016). The Contribution of Wild Plants to Dietary Intakes of Micronutrients: Mineral Elements. M.C. Sánchez-Mata and J. Tardío (Ed.). In: Mediterranean Wild Edible Plants Ethnobotany and Food Composition. (p. 111-140). New York: Springer Publishing.

Gomez, M. and Martinez, M.M. (2017). Fruit and Vegetable ByProducts as Novel Ingredients to Improve the Nutritional Quality of Baked Goods, Critical Reviews in Food Science and Nutrition, $58 \quad$ (13), 2119-2135. doi: 10.1080/10408398.2017.1305946.

Göde, G., Kayaardı, S., Uyarcan, M. and Söbeli, C. (2021) Turkish Food Culture and Nutrition Habits in the Development of History. Food and Health, 7 (3), 216-226. doi: 10.3153/FH21023.

Guil-Guerrero, J.L. and Torija-Isasa, M.E. (2016). Fatty Acid Profiles of Mediterranean Wild Edible Plants. M.C. Sánchez-Mata and J. Tardío (Ed.). In: Mediterranean Wild Edible Plants Ethnobotany and Food Composition. (p. 173-186). New York: Springer Publishing.

Karauğuz, G. (2007). Hititler Döneminde Anadolu'da Ekmek. Tarih Incelemeleri Dergisi, 22 (2), 245-246.

Kayhan, R., Korcan, S. E., Bulduk, I., Kargioğlu, M. and Şelli, E. (2020). Evaluation of Arbutin Content of Three Wild Pear Species Growing in Turkey. Düzce Üniversitesi Bilim ve Teknoloji Dergisi, 8 (1), 81-93.

KTB, (2021). İnce Ekmek Yapma ve Paylaşma Kültürü: Lavaş, Katirma, Jupka, Yufka, Kültür ve Turizm Bakanlı̆̆ Araştırma ve Eğitim Genel Müdürlüğü. https://aregem.ktb.gov.tr/TR- 
202366/ince-ekmek-yapma-ve-paylasma-kulturu-lavaskatirma-jupk-.html erişim tarihi: 30.06.2021.

Kozak, M. (2018). Bilimsel Araştırma: Tasarım, Yazım ve Yayım Ilkeleri. İstanbul:Detay Yayıncilik.

Levent, H. and Bilgiçli, N. (2012). Evaluation of Physical, Chemical and Sensory Properties of Turkish Flat Breads (Bazlama and Yufka) Supplemented with Lupin, Buckwheat and Oat Flours. International Journal of Food Science and Nutrition Engineering, 2 (5), 89-95.

Marco, C. and Rosell, C.M. (2008). Functional and Rheological Properties of Protein Enriched Gluten Free Composite Flours. Journal of Food Engineering, 88 (1), 94-103.

Mastromatteo, M., Danza, A., Guida, M. and Del Nobile, M.A. (2012). Formulation Optimisation of Vegetable Flour-Loaded Functional Bread Part I: Screening of Vegetable Flours and Structuring Agents, International Journal of Food Science and Technology, 47, 1313-1320. doi:10.1111/j.13652621.2012.02975.x.

Molina, M., Pardo-de-Santayana, M. and Tardío, J. (2016). Natural Production and Cultivation of Mediterranean Wild Edibles. M.C. Sánchez-Mata and J. Tardío (Ed.). In: Mediterranean Wild Edible Plants Ethnobotany and Food Composition. (p. 81110). New York: Springer Publishing.

Mülayim, M. (2018). Konya'da Ekmeğin Tarihi. Konastaş Ekmek Fabrikast. Konya: Çetinkaya Ofset.

OGM, (2021). T.C. Tarım ve Orman Bakanlığı, Orman Genel Müdürlüğü.

https://web.ogm.gov.tr/Lists/TibbiAromatikBitkiler/DispForm .aspx ID $=7$ andContentTypeId=0x0100D9FEA1544375754EB 5878A903C35AD54 erişim Tarihi:02.07.2021.

Parafati, L., Restuccia, C., Palmeri, R., Fallico, B. and Arena, E. (2020). Characterization of Prickly Pear Peel Flour as a Bioactive and Functional Ingredient in Bread Preparation. Foods, 9 (9), 1189.

Rahman, T., Akter, S., Sabuz, A. A. and Rana, R. (2021). Characterization of Wheat Flour Bread Fortified with Banana Flour. International Journal of Food Science and Agriculture, 5 (1), 7-11.

Sagbas, H. I., Ilhan, G., Ercisli, S., Anjum, M. A. and Holubec, V. (2021). Characterization of Oleaster-leafed Pear (Pyrus Elaeagrifolia Pall. subsp. Elaeagrifolia) Fruits in Turkey. Agronomy, 11 (3), 430. 
Sánchez-Mata, M.C., Matallana-González, M.C. and Morales: (2016). The Contribution of Wild Plants to Dietary Intakes of Micronutrients: Vitamins. M.C. Sánchez-Mata and J. Tardío (Ed.). In: Mediterranean Wild Edible Plants Ethnobotany and Food Composition. (p. 141-172). New York: Springer Publishing.

Silva, G. J., Souza, T. M., Barbieri, R. L. and Costa de Oliveira, A. (2014). Origin, Domestication, and Dispersing of Pear (Pyrus Spp.). Advances in Agriculture, 541097, 1-8. doi: 10.1155/2014/541097.

Spina, A., Brighina, S., Muccilli, S., Mazzaglia, A., Fabroni, S., Fallico, B. and Arena, E. (2019). Wholegrain Durum Wheat Bread Fortified with Citrus Fibers: Evaluation of Quality Parameters During Long Storage. Frontiers in Nutrition, 6, 13.

Topçu, B., Tacer Caba, Z. and Nilüfer Erdil, D. (2019). Effects of Processing Steps on the Phenolic Content and Antioxidant Activity of Oat Breads. Food and Health, 5 (1), 48-63. doi: 10.3153/FH19006.

Yaver, E. and Bilgiçli, N. (2020). Pseudocereals: Composition, Effect on Nutrition-Health and Usage in Cereal Products. Food and Health, 6 (1), 41-56. doi: 10.3153/FH20006.

Yerlitürk, F.Ü, Arslan, O., Sinan, S., Gencer, N. and Özensoy G, Ö. (2008). Characterization of Polyphenoloxidase from Wild Pear (Pyrus Elaegrifolia). Journal of Food Biochemistry, 32 (3), 368-383.

Yilmaz, K. U., Ercisli, S., Cam, M., Uzun, A., Yilmaztekin, M., Kafkas, E. and Pinar, H. (2015). Fruit Weight, Total Phenolics, Acidity and Sugar Content of Edible Wild Pear (Pyrus Elaeagnifolia Pall.) Fruits. Erwerbs-Obstbau, 57 (4), 179-184.

Yu, Y., Wang, L., Qian, H., Zhang, H. and Qi, X. (2017). Contribution of Spontaneously Fermented Sourdoughs with Pear and Navel Orange for the Bread-Making, LWT - Food Science and Technology, 89, 336-343. doi: 10.1016/j.lwt.2017.11.001.

Zbigniew, S., Beata, Ż., Kamil, J., Roman, F., Barbara, K. and Andrzej, D. (2014). Antimicrobial and Antiradical Activity of Extracts Obtained from Leaves of Three Species of the Genus Pyrus. Microbial Drug Resistance, 20 (4), 337-343. 
Traditional Turkish Sweet Bread Discovered in Famine: Pear Bread 